\title{
Studying the impacts of harvest intensity on site productivity of Ontario's black spruce ecosystems
}

\author{
by Dave M. Morris ${ }^{1}$ and Dan R. Duckert ${ }^{1}$
}

As a result of a Class Environmental Assessment, the Ontario Ministry of Natural Resources (OMNR) was mandated to design and implement a research project pertaining to the effects of fulltree harvesting on long-term site productivity. This project, initiated in 1991, was designed to focus on ecosystem processes and the changes occurring to these processes after harvesting (e.g., quantifying the disruption and recovery) for the black spruce working group. A series of replicated, experimental harvest treatments with varying degrees of biomass removal were conducted on nine core study sites, representing different black spruce ecosites located in northwestern Ontario, Canada. The harvest treatments included: uncut - controls, tree length - delimbed at the stump, full tree - delimbed at the roadside, full-tree chipping - chipped debris was returned to the harvest plot, and whole tree - complete removal of vegetation and forest floor. Each site consisted of 16 plots, three replicates of the four harvest treatments ( $30 \mathrm{~m} \times 30 \mathrm{~m}$ plots) and four replicates of the control plots (50 $\mathrm{m} \times 50 \mathrm{~m}$ plots). Work on this project is anticipated to continue for a minimum of fifteen years to detail the early and most dynamic stages of post-harvest recovery.

Key words: black spruce, site productivity, nutrient cycling, harvesting impacts
En tant qu'element de l'evaluation de type environnemental, le Ministere des Richesses naturelles de l'Ontario (MRNO) a ete mandate pour concevoir et implanter un projet de recherche sur les effets de la recolte par arbre entier sur la productivite a long terme d'une station. Ce projet a ete concu pour porter principalement sur les processus ecosystemiques et sur les changements qui surviennent a ces processus apres la recolte (c'est-a-dire, quantifier la rupture et la recuperation) pour les peuplements d'epinette noire. Une serie de traitements experimentaux de recolte a divers degres d'extraction de la biomasse, ont ete repetes sur neuf principaux sites d'etude, representant differents ecosites d'epinette noire dans le nord ouest de l'Ontario au Canada. Les traitements de recolte comprenaient: non-coupes - temoins, arbres en longueur - ebranches a la souche, troncs entiers - ebranches a la jetee, mise en copeaux de l'arbre entier-les debris du dechiquetage etaient retournes dans la parcelle recoltee, et arbre entier recolte complete de la vegetation et de la litiere forestiere. Chaque site comportait 16 parcelles, trois repetitions des quatre traitements de recolte (parcelles de $30 \mathrm{~m} \times 30 \mathrm{~m}$ ) et quatre repetitions des parcelles temoins (parcelles de $50 \mathrm{~m} \times 50 \mathrm{~m}$ ). Le travail sur ce projet devrait se poursuivre durant au moins quinze ans afin de detailler les etapes initiales ainsi que les plus dynamiques de la recuperation apres recolte.

Mots-cles: epinette noire, productivite de la station, cycle des elements nutritifs, impacts de la recolte

\section{Introduction}

The boreal forest region represents $54 \%$ (43 million hectares) of Ontario's forested land, with $88 \%$ of that considered as productive forests, a significant portion of which is under Sustainable Forest Licenses (SFL) or private land management. Within this region, black spruce is a predominant feature across the landscape, accounting for $40 \%$ of the 1.6 million cubic metres of fibre harvested annually. One reason for the predominance of black spruce in the region is its ability to occupy a number of different ecosites. For example, black spruce is the dominant feature in treed bogs which typically have deep, fibric peatymor soils, high watertables, a reduced number of Frost-Free Days (FFD), and a lower total for Growing Degree-Days (GDD) when compared to boreal uplands. It also can, however, dominate or be a common associate on upland, well-drained, shallow to deep mineral soil sites. As a result, tree growth and overall site productivity (NPP - Net Primary Production) can vary greatly over the range of site types dominated by black spruce (Morris 1997). This variability, once the tree crop has been established and in a free-to-grow stage, is most likely linked to the availability of nutrients (Vitousek 1982, Gordon 1987, Pastor and Bockheim 1984, Morris et al. 1997).

${ }^{1}$ Ontario Ministry of Natural Resources, Centre for Northern Forest Ecosystem Research, clo Lakehead University, 955 Oliver Road, Thunder Bay, Ontario P7B 5E1. E-mail addresses: morrid6@epo.gov.on.ca, duckerda@epo.gov.on.ca

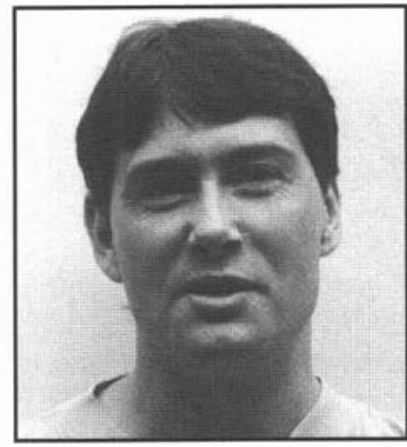

Dave Morris

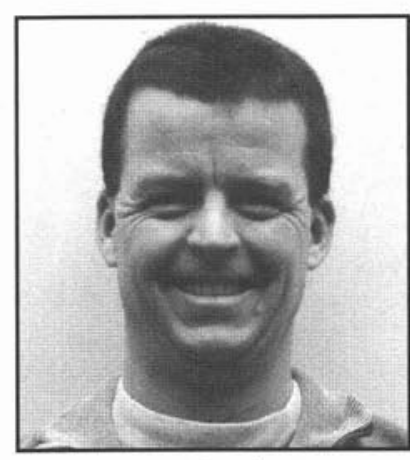

Dan Duckert
Nutrient availability to a crop species is related to: 1) the rate at which nutrient cycling processes occur (e.g., conversion from organic to inorganic forms), 2) competition for water and nutrients from non-crop species, and 3) the loss of nutrients from the site through deep-leaching or disturbance (e.g., soil erosion, wildfire, timber harvesting). It would seem to follow that the maintenance of productivity on some sites may be at risk due to the nutrient removals caused by these standreplacing events. In addition to this nutrient removal issue, other potential impacts on the physical environment can occur as a result of various forest management activities, namely: loss of productive land (i.e., road building, landings, slash/chip piles), 
soil erosion, soil compaction and rutting, and hydrological impacts (Archibald et al. 1997).

In a Class Environmental Assessment by the Ontario Ministry of Natural Resources (OMNR) for Timber Management on Crown Lands, an enormous amount of information was presented by all interested parties regarding the issue of increased nutrient removal caused by full-tree harvesting. This information was largely in one of two forms: scientific evidence (published literature) and expert opinion. As the Board finally determined, the evidence with respect to impacts of intensive logging on certain sites is cautionary (and sometimes contradictory) rather than definitive. The majority of the Ontariobased papers have relied on static sampling to make temporal interpretations, or calculations (e.g., nutrient replacement times) were based on theoretical harvests rather than controlled manipulations, or dealt with a limited number of site types. It was recognized that these approaches did not sufficiently provide detailed information, especially at the process level, to evaluate the potential impacts of harvest-related nutrient removals on long-term site productivity. Also, a large portion of the scientific findings were drawn from other jurisdictions.

The EA examining board granted approval for timber harvest on crown land dependent on a number of Terms and Conditions (T\&Cs). One such $\mathrm{T} \& \mathrm{C}$ which related to the nutrient removal question noted above (T\&C 101) states: "OMNR shall design and implement a study pertaining to the effects of full-tree harvest and full-tree chipping on long-term forest productivity."

The purpose of this paper, within the context of the FERNS (Forest Ecosystem Research Network of Sites) meeting, was to provide an overview and current status of OMNR's site productivity impacts program with specific reference to the experimental harvest trials established in 1994.

\section{Project Background}

The project initiated as a result of $\mathrm{T} \& \mathrm{C} 101$ was designed to focus on ecosystem processes within the black spruce working group and the changes occurring to these processes (e.g., quantifying the disruption and recovery) after harvest (Gordon et al. 1993). The overall objectives of this project were:

1. to quantify the important processes involved in nutrient cycling over a range of black spruce ecotypes;

2. to document the recovery patterns of the above-mentioned processes after timber harvesting and compare these changes to post-wildfire patterns;

3. to identify site types that are sensitive to nutrient removals; and

4. to provide science-based support in the revision or clarification of provincial guidelines and silvicultural ground rules pertaining to the management of these sensitive sites which, in turn, will ensure stable or enhanced levels of site productivity.

Work on this project was begun in 1991 with site selection, followed by two years of pre-harvest inventory and process monitoring (1992-1993). After this pre-harvest work was completed, a series of experimental harvests were conducted, followed up by a detailed post-harvest monitoring program starting in 1994 and continuing to the present time. This work is anticipated to continue for a minimum of fifteen years to detail the early and most dynamic stages of post-harvest recovery.
A companion project is currently being conducted by researchers from the Canadian Forest Service (Project Leader - Dr. Neil Foster) that focusses on jack pine ecosystems. The progress being made on the jack pine work can be found in Tenhagen et al. (1996).

\section{Experimental Design}

To determine if any differential effects of harvesting on longterm productivity of black spruce ecosystems occur as a function of site, a range of site types and productivity levels were selected as part of this project. Three commonly-occurring site types (i.e., moist to wet, organic; fresh to dry, deep mineral soil; fresh to dry, shallow soil), with each site type represented by three levels of productivity, were selected for the project. All nine of these mature ( 80 years + ), fire-origin stands are located in northwestern Ontario (Fig. 1). Six of these experimental harvest sites (4-9) are located approximately $70 \mathrm{~km}$ north of the city of Thunder Bay (latitude: $49^{\circ} 00^{\prime} \mathrm{N}-49^{\circ} 04^{\prime} \mathrm{N}$; longitude: $89^{\circ} 22^{\prime} \mathrm{W}-89^{\circ} 28^{\prime} \mathrm{W}$ ) on the Spruce River Forest (Abitibi Consolidated SFL), two sites (2 and 3) are located approximately $60 \mathrm{~km}$ northeast of the community of Nakina (latitude: $50^{\circ} 25^{\prime} \mathrm{N}$; longitude: $86^{\circ} 13^{\prime} \mathrm{W}$ ) on the Nagagami Forest (Kimberly Clark Inc. SFL), and one site (site 1) is situated in the Geraldton Community Forest (latitude: $49^{\circ} 44^{\prime} \mathrm{N} ; 86^{\circ} 57^{\prime} \mathrm{W}$ ).

A series of replicated, experimental harvest treatments with varying degrees of biomass removal were conducted on the nine core study sites. These harvest treatments included: 1) uncut - controls, 2) tree length - delimbed at the stump, 3) full-tree - delimbed at the roadside, 4) full-tree chipping - chipped debris was returned to the harvest plot, and 5) whole-tree - complete removal of vegetation and forest floor. Each site consisted of 16 plots, three replicates of the four harvest treatments ( $30 \mathrm{~m}$ $\times 30 \mathrm{~m}$ plots) and four replicates of the control plots $(50 \mathrm{~m} \times$ $50 \mathrm{~m}$ plots). The increased size and inclusion of a fourth control plot was done to provide added protection against the potential of blowdown occurring along the edge of the adjacent harvested area. Buffer strips between the harvest plots were at least 20 metres and 5 metres between controls. For each site, a general survey (vegetative structure, topography, soils) was conducted prior to plot establishment to delineate areas which didn't conform to the specified site type. It is not uncommon that stand designations for the purposes of forest inventories may include small areas of differing site types. In this type of controlled experiment, however, it is critical that only the variability for a given site type be captured.

Additional fire-origin stands, varying in time since disturbance (Fig. 1: site 10-17 years, site $11-45$ years, site $12-50$ years, site $13-75$ years, site $14-90$ years, site $15-90$ years), were selected to describe and compare stand development, and associated ecosystem processes, after natural disturbance (i.e., wildfire) to that occurring after timber harvesting. The control plots at site 7 (stand age -110 years) represent the endpoint for this wildfire chronosequence. This chronosequence consists of sites that are representative of shallow, medium-textured (loam), conifer-dominated, boreal uplands. Plans have been made to add another wildfire chronosequence (deep, coarse-textured soils) to the plot network beginning in the summer of 1999.

\section{Experimental Harvest Treatments}

The experimental harvest of sites 1-3 (fresh sites in Geraldton/Nakina) was done in the late winter of 1994 . The 


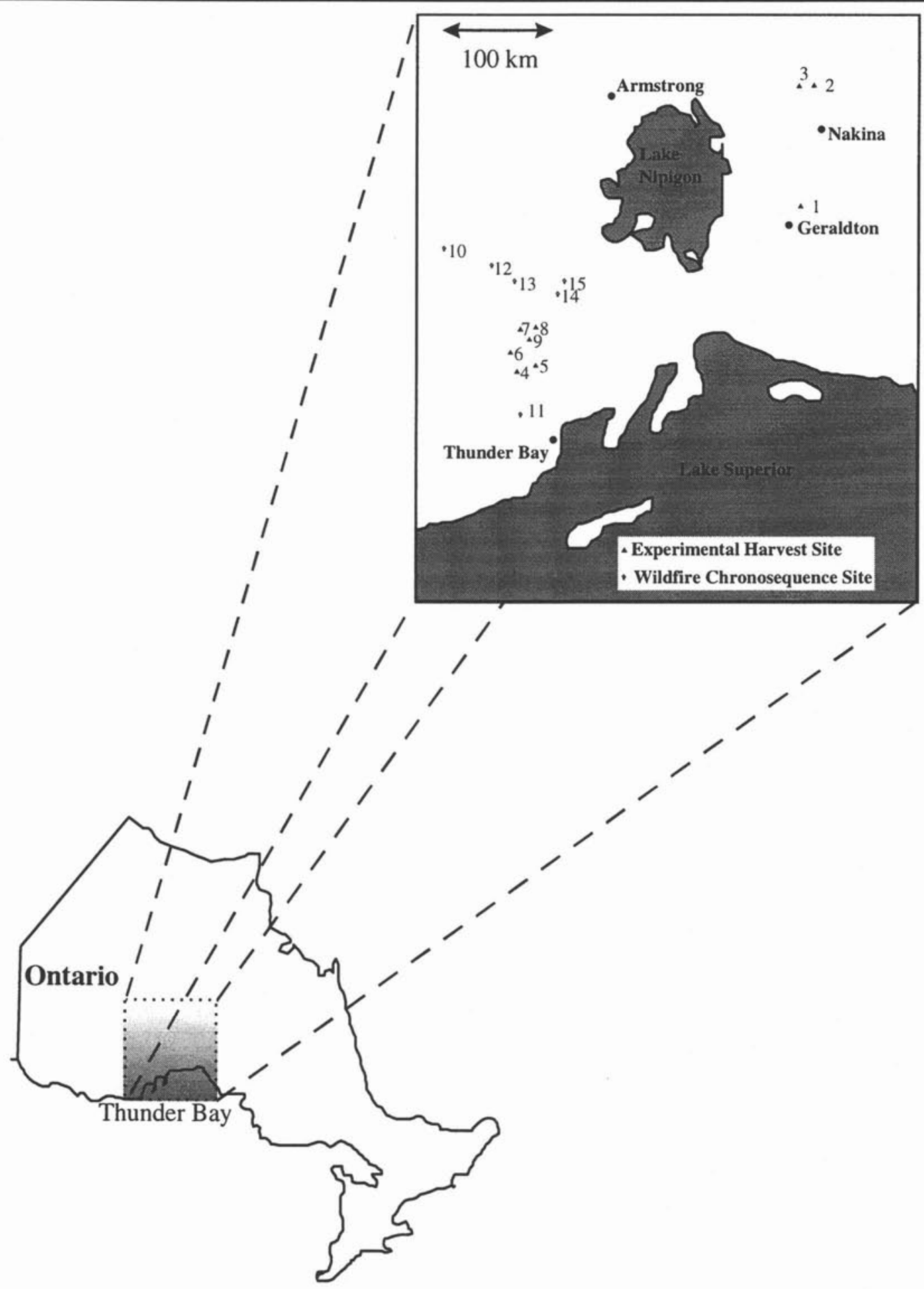

Fig. 1. Site locations for OMNR's black spruce experimental harvest trial and wildfire chronosequence study.

remaining areas (sites 4-9, located near Thunder Bay) were harvested in the winter of 1995. Fig. 2 provides examples of the operations associated with the four harvest treatments. The majority of the harvest operations were done mechanically, utilizing a feller buncher, grapple skidder and delimber. On all but site 1 , the tree length treatment was accomplished by skidding tree bundles to the nearest plot edge and having the mechanical delimber operate overtop of the plot (i.e., swinging the delimbing boom around the plot as it was delimbing). Some manual redistribution of slash was required to ensure uniform distribution across the plot. On site 1, delimbing was done manually (i.e., chainsaw) at the stump, as shown in Fig. 2 (Plate A), as a mechanical delimber was not available. To simulate a chipping operation (Fig. 2 - Plate C), the trees 


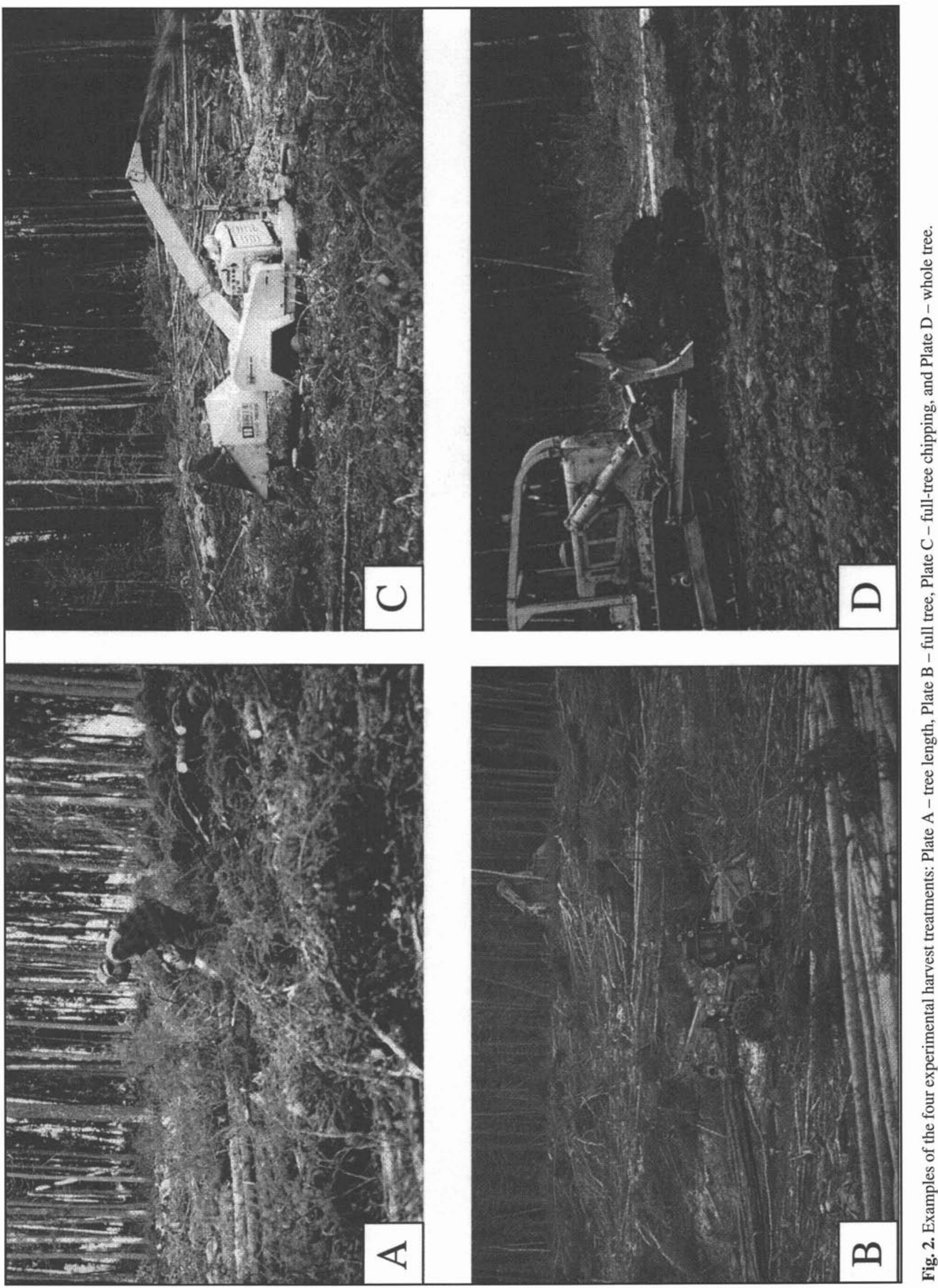


Table 1. Descriptions of the pre-harvest studies conducted to characterize the structure and function of Ontario's black spruce ecosystems.

\begin{tabular}{|c|c|c|c|}
\hline \multicolumn{2}{|c|}{ Study title } & Status & Duration \\
\hline \multicolumn{4}{|c|}{ Defining Structural Characteristics (all sites): } \\
\hline 1 & $\begin{array}{l}\text { Describing the vegetative structure for a range of mature, black spruce-dominated ecosites: } \\
\text { Quantifying the carbon and macroelement pool sizes and tree productivity. }\end{array}$ & completed & $\begin{array}{l}1992-93 \\
(2 \text { yrs. })\end{array}$ \\
\hline 2 & $\begin{array}{l}\text { Describing the chemical nature of the soils associated with black spruce ecosystems and } \\
\text { determining their relationship to aboveground productivity. }\end{array}$ & completed & $\begin{array}{l}1992-93 \\
(2 \text { yrs. })\end{array}$ \\
\hline 3 & Describing the soil seed banks for a range of mature, black spruce-dominated ecosites. & completed & $\begin{array}{l}1992 \\
(1 \mathrm{yr} .)\end{array}$ \\
\hline \multicolumn{4}{|c|}{ Process-oriented Studies (intensive sites only): } \\
\hline 4 & $\begin{array}{l}\text { Describing the biogeochemical cycle for different black spruce ecosites: Quantification of } \\
\text { precipitation and litterfall fluxes. }\end{array}$ & ongoing & $\begin{array}{l}1993- \\
(5+\text { yrs. })\end{array}$ \\
\hline 5 & $\begin{array}{l}\text { Describing important hydrological properties (i.e., infiltration and percolation rates) for different } \\
\text { black spruce ecosites as they relate to nutrient movement, retention, and leaching potentials. }\end{array}$ & ongoing & $\begin{array}{l}1993- \\
(5+\text { yrs. })\end{array}$ \\
\hline 6 & $\begin{array}{l}\text { Determining the turnover rates of soil organic matter components (i.e., fresh litters, forest humus, } \\
\text { fine root material) for different black spruce ecosystems. }\end{array}$ & ongoing & $\begin{array}{l}1995- \\
(3+\text { yrs. })\end{array}$ \\
\hline 7 & Determining the importance of biochemical cycling (nutrient resorption) in black spruce ecosystems. & ongoing & $\begin{array}{l}1997- \\
(1+\text { yrs. })\end{array}$ \\
\hline 8 & $\begin{array}{l}\text { Comparing the microclimate profiles for contrasting black spruce ecosites and determining the } \\
\text { relationship of these regulatory factors to key soil processes. }\end{array}$ & ongoing & $\begin{array}{l}1993- \\
(5+\text { yr. })\end{array}$ \\
\hline
\end{tabular}

from a designated plot were skidded to a plot corner, delimbed with a chainsaw and the slash was fed through a 12 inch gaspowered brush chipper. The chipped material was weighed and spread, uniformly, over the plot. The whole-tree harvest treatment (Fig. 2 - Plate D) was accomplished by running a D8 bulldozer over full-tree-harvested plots in order to remove the slash and duff layers. On the organic sites, and some of the mineral sites due to their irregular topography, only the upper portion of the organic layer was removed. The extent (depth) of this removal was measured for the whole-tree plots on these sites.

In order to better isolate the effects of the harvest treatments (varying levels of organic matter and nutrient removals) on postharvest recovery patterns (e.g., soil carbon and nutrient dynamics, regeneration potential and stand development patterns, and plant nutrition and productivity), mechanical site preparation was not conducted prior to planting. Each $30 \mathrm{~m} \times 30 \mathrm{~m}$ plot was divided into four quadrants ( $15 \mathrm{~m} \times 15 \mathrm{~m}$ subplots), with three of these quadrants being planted ( $2 \mathrm{~m}$ spacing, providing approximately 50 seedlings per quadrant) in the spring following the harvesting with black spruce seedlings (overwintered, containerized stock). The remaining, unplanted quadrants were left to study the natural regeneration potential of the various harvest treatment/site type combinations. The $20 \mathrm{~m}$ buffer strips surrounding, and between, the plots were also planted to minimize to potential for plot "edge" effect.

\section{Field Studies}

A number of pre-harvest studies, listed in Table 1, were started in the spring of 1992 and were, for the most part, completed in 1995. A portion of these studies have been continued in the control plots to document the inherent annual fluctuations associated with key ecosystem processes (e.g., litterfall). The studies can be separated into two distinct categories: 1) studies designed to characterize the structural characteristics of the different black spruce-dominated ecosites, and 2) studies designed to obtain accurate rates of key above- and below-ground ecosystem processes. Due to the enormous amount of time and resources required to conduct these process-oriented studies, they were only conducted on three of the study sites representing important, and ecologically different, black spruce ecosites. The ecosites chosen for these process studies, as described in Racey et al. (1996), were: 1) an ES36 (Intermediate Black Spruce Swamp ecosite) occupying a lowland, poorly-drained, wet mineral site, 2) an ES35 (Poor Black Spruce Swamp ecosite) which supports a treed wetland developed on organic substrate, and 3) an ES20 (Spruce-Pine/feathermoss ecosite) occupying an upland, shallow-soiled, very fresh site. These sites were referred to as the "intensive" sites in the original protocols document (Gordon et al. 1993) and correspond to sites 5 (ES35), 6 (ES36), and 7 (ES20) in Fig. 1. The expectation is that the information generated from these studies (e.g., a gradient of process rates linked to key regulatory factors) would be applied, in a modelling context, to the other site types and stand conditions included in this project. To date, studies 1, 2, 4 (litterfall only), and 6 have also been conducted on the wildfire chronosequence sites (Fig. 1: sites 10-15) to describe the patterns in ecosystem recovery after natural disturbance.

A number of post-harvest studies were started in the spring following the experimental harvest and have been carried through to the present (Table 2). For the most part, these studies represent "companions" to the pre-harvest studies with the principal focus, and corresponding experimental design and sampling scheme, being to isolate the harvest treatment effects on the restoration (resilience) of ecosystem function and, ultimately, site productivity. In addition, the site array included in this project permits the examination/detection of any differential effects related to site (i.e., site type $\times$ harvest treatment interactions). As with the approach used in the pre-harvest studies, the majority of the process-oriented studies to date have been conducted on the three intensive sites.

Detailed descriptions (e.g., study objectives, experimental design, sampling protocols) of both the pre-harvest and postharvest studies can be found in the project's establishment report (Duckert and Morris 1999). 
Table 2. Descriptions of the post-harvest studies currently being conducted to determine the harvest treatment effects on the restoration (recovery) of ecosystem function.

\begin{tabular}{|c|c|c|c|}
\hline \multicolumn{2}{|c|}{ Study title } & Date initiated & Sampling schedule $^{1}$ \\
\hline \multicolumn{4}{|c|}{ Defining Structural Characteristics (all sites): } \\
\hline 1 & $\begin{array}{l}\text { Documenting the post-harvest slash loadings associated with the different harvest } \\
\text { treatments over a range of different black spruce-dominated ecosites. }\end{array}$ & $1994 / 5^{2}$ & Time 0 \\
\hline 2 & $\begin{array}{l}\text { Describing the developmental patterns (e.g., regeneration potential, species composition, } \\
\text { NPP, crop tree performance) associated with different harvesting intensities for a range of } \\
\text { black spruce-dominated ecosites. }\end{array}$ & $1997 / 8$ & Year $4,7,10,15$ \\
\hline 3 & $\begin{array}{l}\text { Determining the effects of harvest treatment on the physical and chemical properties of the } \\
\text { soils associated with black spruce ecosystems and linking these differences to aboveground } \\
\text { productivity. }\end{array}$ & $1994 / 5$ & Year $0,4,7,10,15$ \\
\hline \multicolumn{4}{|c|}{ Process-oriented Studies (intensive sites only): } \\
\hline 4 & $\begin{array}{l}\text { Identifying changes to important hydrological properties (i.e., infiltration and percolation rates) } \\
\text { as a function of harvest treatment for different black spruce ecosites: Development of nutrient } \\
\text { movement, retention, and leaching profiles. }\end{array}$ & 1995 & Year $0-5,10-15$ \\
\hline 5 & $\begin{array}{l}\text { Describing the recovery pattern (e.g., timing and pattern)of the biogeochemical cycle associated } \\
\text { with differing levels of harvest intensity for different black spruce ecosites. }\end{array}$ & 1995 & Year $0-5,10-15$ \\
\hline 6 & $\begin{array}{l}\text { Determining the effects of different harvest intensities on the turnover rates of soil organic matter } \\
\text { components (i.e., slash and fine litter residues, forest humus) for different black spruce ecosystems. }\end{array}$ & 1995 & Year $0-5,10-15$ \\
\hline 7 & $\begin{array}{l}\text { Comparing the microclimate profiles resulting from different harvest treatments for contrasting black } \\
\text { spruce ecosites and determining the relationship of these regulatory factors to key soil processes. }\end{array}$ & 1995 & Year 0-15 \\
\hline
\end{tabular}

\section{Project Coordination}

In 1991, a joint Provincial-Federal Sustainable Productivity Technical Working Group (cochairs: Dave Morris, OMNR; Neil Foster, CFS) was established to coordinate Ontario's research efforts in the area of sustainable productivity of forest ecosystems, and, as such, has been overseeing the work being conducted on both the OMNR and CFS experimental harvest projects since they were initiated. As a tactical (short-term) objective, the working group was charged with the task of developing the experimental design and sampling protocols for the experimental projects (OMNR - Gordon et al. 1993; CFS Tenhagen et al. 1996) to ensure that a common approach was used in these projects. As a strategic objective, the working group identifies new opportunities or needs for site productivity research (e.g., criteria and indicators of soil quality, forest ecosystem modelling) within the context of provincial, nation$\mathrm{al}$, and international programs. In keeping with this objective, D. Morris and N. Foster both participate at the annual LTSP (Long-term Site Productivity) Technical Committee meetings (chaired by Bob Powers, Pacific Southwest Research Station) which oversees the United States' national program of longterm site productivity research (Powers et al. 1990).

Ontario's Technical Working Group is not, however, in itself, a funding body. Therefore, new study proposals in subject areas identified as requiring further research must be directed to the appropriate funding agencies. With respect to OMNR's project, funding to date has come exclusively from within OMNR's Science, Technology, and Information Branch as part of its Forest Management Business Plan. Largely as a function of this sole source for project funding, OMNR researchers have conducted the majority of the studies to date and continue to be responsible for collecting a core set of measurements in adherence to the project objectives and protocols. With "seed" money from the project's core budget, additional partners from Lakehead University (N. Luckai - microbial community studies) and the University of Guelph (A.M. Gordon - litter decomposition and $\mathrm{N}$-mineralization studies) have, recently, established or completed experiments on the black spruce study sites that compliment OMNR's efforts.

\section{Project Deliverables}

In keeping with the original objectives and intent of the project, it is anticipated that one of the major contributions (e.g., supporting data, training sessions led by research team members) from this project will be through the development, revision, implementation, and compliance monitoring of forest management guidelines (e.g., Silvicultural Guides, Physical Site Protection Guidelines, Forest Management Planning Manual) designed to ensure stable or enhanced levels of site productivity within Ontario's spruce working group. In keeping with this expectation, project data and results generated to date have been of interest to an array of audiences, including other researchers, policy makers, and operational personnel. As a result, project communications have also come in a variety of forms: journal publications (5), technical reports (9), student theses (7), and workshop presentations (29). In addition, the current status and recent results of the project are updated as part of CNFER's (Centre for Northern Forest Ecosystem Research) web page (http://www.cnfer.on.ca/html/fulltree.html). Project-related publications may be found at and requested from this site.

\section{Project Pitfalls - "Lessons Learned"}

Although OMNR's experimental harvest project is “alive and well", it is not to say that there have not been valuable lessons to be learned from the project's history. First and foremost, it is essential that any long-term, multi-partnered research project has a project manager assigned to the research team. Although this individual needs to be fully aware of the science to be conducted, and may cooperate on some of the research studies being conducted, their principal responsibilities should 
be: 1) to coordinate research activities on the experimental sites, 2) to facilitate communication between researchers and to target audiences, and 3) to actively pursue funding opportunities. With respect to this funding function, it is essential that the project manager continues to actively "champion" the project within the relevant funding agencies. The bottom line here is that securing "startup" funding for a given long-term project does not guarantee continued support. It is not uncommon for funding agencies or committees to change their focus or interest, requiring repeated efforts to emphasize the continuing importance and relevance of the project in question. The importance of and the time required to effectively carry out this and the other project manager functions should not be underestimated. Based on the experience with OMNR's experimental harvest project, these tasks cannot be effectively carried out by the individual researchers working on the project.

In connection with the long-term funding issue noted above, the best way to ensure funding stability, is to seek out and secure funding from a number of different sources. This tends to occur once the project is well-established with a good record of "defendable" science outputs. Projects funded via a sole source, although administratively less complex, are far more vulnerable to funding constraints or shifts in emphasis by the sponsoring agency.

Despite certain weaknesses in project funding and delivery, OMNR's experimental harvest project, and the results being generated by the research team, will continue to contribute to our understanding of the impacts of forest management practices on forest ecosystem processes, and, thereby, move our management approaches towards sustainable forestry.

\section{References}

Archibald, D.J., W.B. Wiltshire, D.M. Morris and B. Batchelor. 1997. Forest management guidelines for the protection of the physical environment. Queen's Printer, Toronto. 42 p.
Duckert, D.R. and D.M. Morris. 1999. Impacts of harvest intensity on long-term site productivity on black spruce ecosystems: An Establishment Report. Queen's Printer, Toronto. (in press).

Gordon, A.G., D.M. Morris and N. Balakrishnan. 1993. Impacts of various levels of biomass removals on the structure, function, and productivity of black spruce ecosystems: Research Protocols. Ont. Min. Nat. Res., For. Res. Info. Paper No. 109. 21 p.

Gordon, A.M. 1987. Seasonal patterns of nitrogen mineralization and nitrification following harvesting in the white spruce forests of interior Alaska. Ph.D. Dissertation, Univ. of Alaska, Fairbanks, Alaska. 364 p.

Morris, D.M. 1997. The role of long-term site productivity in maintaining healthy ecosystems: A Prerequisite of Ecosystem Management. For. Chron. 73: 731-740.

Morris, D.M., J.P. Kimmins and D.R. Duckert. 1997. The use of soil organic matter as a criterion of the relative sustainability of forest management alternatives: A modelling approach using FORECAST. For. Ecol. Manage. 94: 61-78.

Pastor, J. and J.G. Bockheim. 1984. Distribution and cycling of nutrients in an aspen-mixed-hardwood-spodosol ecosystem in northern Wisconsin. Ecology 65: 339-353.

Powers, R.F., D.H. Alban, G.A. Ruark and A.E. Tiarks. 1990. A soils research approach to evaluating management impacts on longterm productivity. In W.J. Dyck and C.J. Mees (eds.). Impact of intensive harvesting on forest productivity. pp. 127-145. Forest Research Institute, Rotorua, New Zealand, IEA/BE T6/A6 Report No. 2, FRI Bulletin No. 159. 257 p.

Racey, G.D., A.G. Harris, J.K. Jeglum, R.F. Foster and G.M. Wickware. 1996. Terrestrial and wetland ecosites of northwestern Ontario. Ont. Min. Natur. Resour., Northwest Sci. \& Technol. Field Guide FG$02.94 \mathrm{p}$.

Tenhagen, M.D., J.K. Jeglum, S. Ran and N.W. Foster. 1996. Effects of a range of biomass removals on long-term productivity of jack pine ecosystems: Establishment Report. Nat. Resour. Can., Can. For. Serv., Info. Rep. O-X-454. 13 p.

Vitousek, P.M. 1982. Nutrient cycling and nutrient use efficiency. Am. Nat. 119: 553-572. 